\title{
Elevated Expression of Transforming Growth Factor- $\beta$ in Adipose Tissue from Obese Mice
}

\author{
Fahumiya Samad, Koji Yamamoto, Manjula Pandey, \\ and David J. Loskutoff \\ The Scripps Research Institute, Department of Vascular Biology, \\ La Jolla, California, U.S.A.
}

\begin{abstract}
Background: Tumor necrosis factor- $\alpha$ (TNF- $\alpha$ ) is chronically elevated in the adipose tissue from obese humans and mice. This increase in TNF- $\alpha$ contributes to the insulin resistance, elevated plasminogen activator inhibitor-1 (PAİ-1) levels, and cardiovascular complications associated with obesity and noninsulin-dependent diabetes (NIDDM). PAI-1 gene expression in adipose tissue is also stimulated by transforming growth factor- $\beta$ (TGF- $\beta$ ). Experiments were performed to determine whether TGF- $\beta$ is regulated by TNF- $\alpha$ and elevated in obesity.

Materials and Methods: The concentration of TGF- $\beta$ and PAI-1 mRNA in murine adipose tissue and cultured 3T3-Ll adipocytes was determined by quantitative reverse transcription polymerase chain reaction (RT-PCR), and the cellular localization of these molecules was evaluated using in situ hybridization and cell fractionation. Total TGF- $\beta$ protein was determined by employing an ELISA assay.
\end{abstract}

\begin{abstract}
Results: TGF- $\beta$ mRNA and protein were increased in the adipose tissue from two different strains of genetically obese mice (i.e., ob/ob and $\mathrm{db} / \mathrm{db}$ ), compared with their lean counterparts. This increase in TGF- $\beta$ may result from TNF- $\alpha$ since TNF- $\alpha$ increased TGF- $\beta$ mRNA expression in the adipose tissue of lean mice and stimulated TGF- $\beta$ production by cultured adipocytes. Administration of TGF- $\beta$ increased PAI- 1 antigen in the plasma and PAI-1 mRNA in the adipocytes of lean mice, and enhanced the rate of PAI-1 synthesis by adipocytes in vitro.

Conclusions: TNF- $\alpha$ contributes to the elevated TGF- $\beta$ expression demonstrated in the adipose tissue of obese mice. A potential role for TGF- $\beta$ in the increased PAI- 1 and vascular pathologies associated with obesity/NIDDM is suggested.
\end{abstract}

\section{INTRODUCTION}

Obesity is a risk factor for the development of cardiovascular disease $(1,2)$ and is associated with metabolic disorders such as hypertriglyceridemia, hyperinsulinemia, and noninsulin-dependent diabetes (NIDDM) (2,3). Interestingly, a number of clinical studies also have demonstrated a correlation between obesity and elevated plasma PAI-1 (4-7). PAI-1 is the primary physiological inhibitor of plasminogen activation in vivo $(8,9)$, and increases in plasma PAI-1 are also associated with increased risk for cardio-

Address correspondence and reprint requests to: David J. Loskutoff, Ph.D., The Scripps Research Institute, $10550 \mathrm{~N}$. Torrey Pines Road, VB-3, La Jolla, CA 92037, U.S.A. vascular disease (10). Although the importance of the link between obesity and elevated PAI-1 has long been recognized, the molecular basis of this connection remains elusive. In this regard, surgical treatments that cause rapid weight loss in obese individuals lead to a rapid reduction in plasma PAI-1 activity and clot lysis time (11). This observation suggests that the adipose tissue itself may produce PAI- 1 and/or cytokines that regulate PAI-1 gene expression in vivo. This hypothesis is supported by the findings that plasma PAI-1 is increased 4- to 5-fold in genetically obese mice when compared with their lean counterparts, and that PAI-1 mRNA is elevated in the adipose tissues of these mice (12).

Studies of obese rodents and humans dem- 
onstrate that tumor necrosis factor- $\alpha$ (TNF- $\alpha$ ) is elevated in the adipose tissue and that expression of TNF- $\alpha$ is strongly correlated with insulin resistance and hyperinsulinemia $(13,14)$. Interestingly, TNF- $\alpha$ stimulates PAI- 1 expression in a variety of cultured cells and in most murine tissues $(15,16)$. In obese humans, elevations in plasma PAI-1 also appear to correlate with high plasma insulin levels (17), and PAI-1 levels have been shown to be directly correlated with insulin resistance $(5,18,19)$. These observations raise the possibility that the elevated levels of plasma PAI- 1 in obesity may arise from increased synthesis of PAI-1 by the adipose tissue in response to TNF- $\alpha$ and/or insulin. In this regard, we have demonstrated that direct administration of insulin or TNF- $\alpha$ to lean mice stimulates PAI- 1 gene expression in the adipose tissue $(12,20,21)$.

In addition to TNF- $\alpha$ and insulin, the major inducer of PAI-l in the adipose tissue appears to be transforming growth factor- $\beta$ (TGF- $\beta$ ) (21). In this study, we investigate whether TGF- $\beta$ itself is regulated in obesity. We demonstrate that TGF- $\beta$ gene expression is elevated in the adipose tissues from genetically obese mice, and that its expression in vivo and in vitro is regulated by TNF- $\alpha$. We also show that TGF- $\beta$ induces PAI- 1 mRNA in the adipocytes in vivo and in vitro. These results suggest that TGF- $\beta$ may contribute to the various pathologies associated with obesity and NIDDM, and it may play a significant role in the regulation of PAI- 1 in obesity.

\section{MATERIALS AND METHODS}

\section{Animals and Tissue Preparation}

Adult male CB6 mice (BalbC/ByJ X C57BL6/J), weighing 25-30 g, were obtained from the Scripps Rodent Breeding Colony. Adult male obese mice (C57BL/6J ob/ob; C57BL/KsJ/ db/ $\mathrm{db})$, aged 8-12 weeks, and their lean counterparts (C57BL/6J +/?; C57BL/KsJ +/?) were obtained from Jackson Labs (Bar Harbor, ME). CB6 mice were injected intraperitoneally with the indicated amount of human recombinant TGF- $\beta$ (Sigma Chemical Company, St. Louis, MO) dissolved in $4 \mathrm{mM} \mathrm{HCl}$ containing $0.1 \% \mathrm{BSA}$, or with recombinant murine TNF- $\alpha(4 \mu \mathrm{g} /$ mouse in saline; kind gift of Dr. Richard Ulevitch, The Scripps Research Institute). Control mice were injected with an equivalent amount of $4 \mathrm{mM}$ $\mathrm{HCl} / 0.1 \% \mathrm{BSA}$ or saline, respectively. For in vivo insulin experiments, lean mice (C57BL/6J +/?) were injected intraperitoneally with 10 units of regular human insulin (Humilin R; Eli Lilly, Indianapolis, IN), while the controls were injected with an equivalent volume of saline alone. At the conclusion of each experiment, mice were anesthetized by metofane (Pitman-Moore, Mundelein, IL), blood samples were collected into $20 \mathrm{mM}$ EDTA (final concentration), and epididymal fat pads were removed and processed for in situ hybridization analysis and preparation of total RNA as previously described (20).

\section{Determination of PAI-1 Activity in Plasma}

Active PAI-1 antigen in plasma was determined using the t-PA binding assay as previously described (22). The polyclonal rabbit anti-mouse PAI- 1 antibody used in this assay was prepared against purified, recombinant mouse PAI-1. Recombinant mouse PAI-1 was a kind gift from Drs. D. Lawrence and D. Ginsburg, Howard Hughes Medical Institute, University of Michigan Medical Center, Ann Arbor, Michigan. In this assay, active PAI- 1 levels $(\mathrm{ng} / \mathrm{ml})$ were calculated from a standard curve constructed using recombinant mouse PAI-1.

\section{Quantitative Reverse Transcription Polymerase Chain Reaction (RT-PCR)}

The concentrations of PAI- 1 and TGF- $\beta$ mRNA were determined by quantitative RT-PCR using a competitor cRNA containing upstream and downstream primers for PAI-1, TGF- $\beta$, and $\beta$-Actin as previously described $(23,24)$. After reverse transcription (using either $10^{6}$ or $10^{7}$ molecules of CRNA for PAI- $1,10^{5}$ molecules for TGF- $\beta$, and $10^{7}$ molecules for $\beta$-actin, optimized in previous preliminary experiments) and PCR (25), $20 \mu \mathrm{l}$ of the PCR products were electrophoresed on $1.8 \%$ agarose gels. The appropriate bands corresponding to the internal standard cRNA product and the target mRNA product were excised from the gel and the incorporated radioactivity quantified using a scintillation counter. A standard curve for the internal control cRNA was constructed and used to determine the specific activity of the target mRNA as previously described $(20,24)$. Variations in sample loading were assessed by measuring $\beta$-actin mRNA. 


\section{Riboprobe Preparation and In Situ Hybridization}

A subclone of mouse PAI-1 cDNA containing nucleotides 1-1085 in the vector pGEM-3Z was used to prepare a riboprobe for in situ hybridization (26). This vector was linearized with EcoRI (antisense) or HindIII (sense) and used as a template for in vitro transcription of radiolabeled antisense or sense riboprobes employing SP6 or T7 RNA polymerase, respectively, in the presence of $\left[{ }^{35} \mathrm{~S}\right] \mathrm{UTP}(>1,200 \mathrm{Ci} / \mathrm{mmol}$; Amersham Corp., Arlington Heights, IL). A 974 bp fragment of the mouse TGF- $\beta$ cDNA (kindly provided by Dr. Rik Derynck, Genentech, Inc; [27]) was subcloned into the vector pSP73 and used to generate TGF- $\beta$-specific riboprobes. In situ hybridization was performed as described previously using the above ${ }^{35} \mathrm{~S}$-labeled riboprobes (26). Both sense and antisense probes were routinely labeled to specific activities between 0.5 and $2 \times$ $10^{8} \mathrm{cpm} / \mu \mathrm{g}$ RNA. Slides were exposed in the dark at $4^{\circ} \mathrm{C}$ for 4 to 12 weeks.

\section{Tissue Digestion and Cell Fractionation}

Epididymal fat pads were isolated from mice, washed in sterile PBS, minced, and washed in Krebs-Ringer Bicarbonate (KRB) buffer (pH 7.4) containing $4 \%$ albumin and $5 \mathrm{mM}$ glucose (28). The tissues were then treated with collagenase $\left(2 \mathrm{mg} / \mathrm{ml}\right.$; Sigma) on a shaking platform at $37^{\circ} \mathrm{C}$ for $\mathrm{l} \mathrm{hr}$. Undigested tissue was removed with forceps, and the adipocytes were then separated from other cells by their ability to float upon low-speed $(200 \mathrm{~g})$ centrifugation. To obtain the total stromal-vascular fraction, the medium below the adipocyte layer was centrifuged at $500 \mathrm{~g}$ for $10 \mathrm{~min}$, and the pellet was collected and washed three times with warm KRB buffer. Total RNA was extracted from the two fractions and the amount of PAI- 1 or TGF- $\beta$ mRNA associated with each was determined by quantitative RTPCR as described above.

\section{TGF- $\beta$ Protein Production by Adipose Tissue}

Local TGF- $\beta$ protein production over $24 \mathrm{hr}$ was determined in explanted adipose tissues from 6-month-old ob/ob mice and their lean counterparts. Epididymal fat pads were dissected under sterile conditions, weighed, and then rinsed first in sterile phosphate-buffered saline (PBS) and then in sterile Krebs-Ringer bicarbonate (KRB) buffer ( $\mathrm{pH} 7.4$ ) containing $4 \%$ serum albumin. The tissue was minced and incubated in a medium containing Dulbecco's modified Eagle's/ Ham's F- 12 supplemented with $10 \%$ FBS; 5 mM glutamine; penicillin $(6.35 \mathrm{mg} / \mathrm{ml})$; and streptomycin $(5 \mathrm{mg} / \mathrm{ml})$ in 6 -well tissue culture plates at $37^{\circ} \mathrm{C}$. The conditioned medium was collected after $24 \mathrm{hr}$ and total TGF- $\beta$ protein (i.e., after acid activation) was determined using the PREDICTA ELISA assay (Genzyme, MA). Since fetal bovine serum (FBS) used for the above cultures may contain TGF- $\beta$, an organ culture medium control was activated and run in the assay. At the end of the experiment, total DNA was extracted from the epididymal fat pads used in each experiment as described (29), and TGF- $\beta$ values expressed both as ng TGF- $\beta / \mathrm{mg}$ of DNA and ng TGF- $\beta / \mathrm{g}$ of tissue.

\section{Cell Culture}

3T3-L1 mouse embryo fibroblasts were obtained from the American Type Culture Collection. The culturing of these cells and their differentiation from preadipocytes into mature adipocytes was carried out as described previously (30). Total RNA was isolated from untreated mature adipocytes, and from mature adipocytes treated with insulin (bovine insulin, Sigma), TNF- $\alpha$, or TGF- $\beta$ as indicated. Conditioned medium was collected from untreated and treated adipocytes for determination of PAI-1 antigen levels.

\section{Western Blot Analysis}

Conditioned medium $(20 \mu \mathrm{l})$ from untreated and TGF- $\beta$-treated adipocytes was electrophoresed under nonreducing conditions on a $9 \%$ SDSPAGE gel and transferred to PROTRAN nitrocellulose membranes (Schleicher \& Schuell, Keene, $\mathrm{NH})$. PAI-l antigen was detected using a polyclonal rabbit antiserum specific for murine PAI- 1 , and the ECL system (Amersham) as previously described (12).

\section{RESULTS}

\section{Tissue Distribution and Cellular Localization of TGF- $\beta$ mRNA in Lean and Obese Mice}

Previous studies showing that TGF- $\beta$ stimulates PAI-l gene expression in the adipose tissues of normal CB6 mice (21), combined with the dem- 

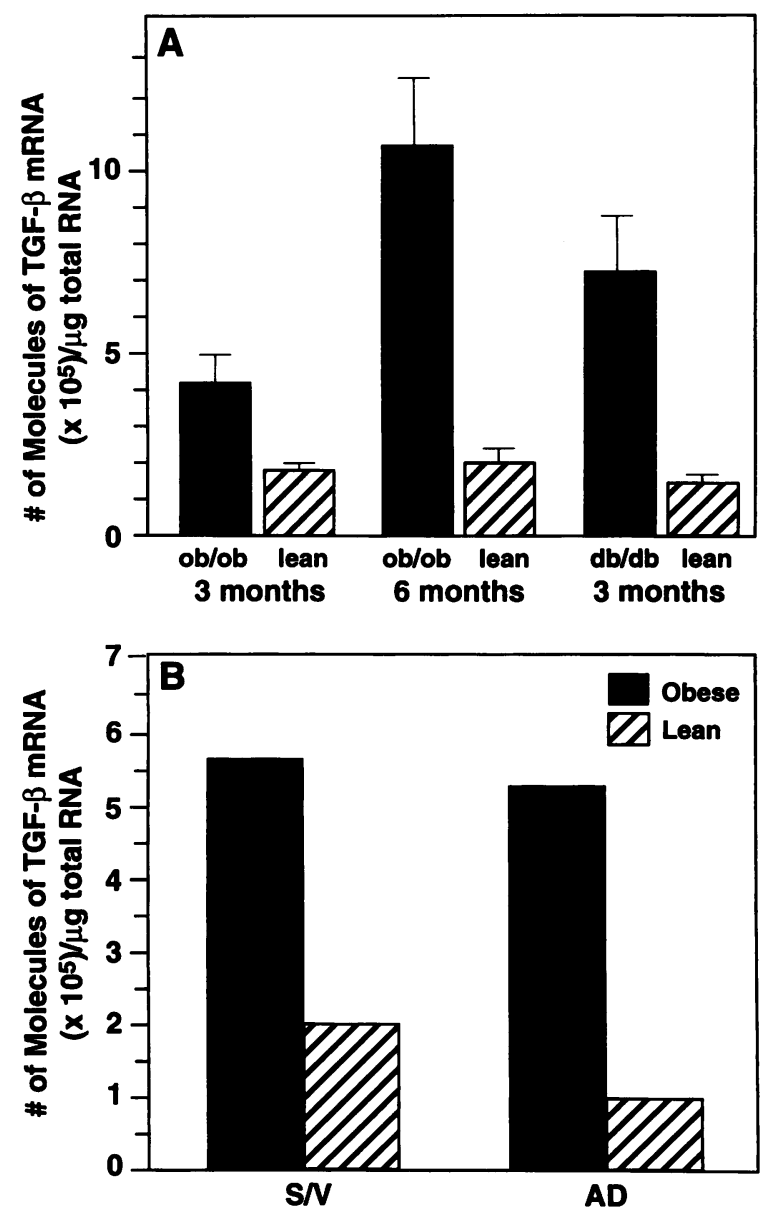

FIG. 1. Expression of TGF- $\beta$ mRNA in adipose tissues from lean and obese mice.

(A) Total RNA was extracted from epididymal fat pads of male lean and obese (ob/ob; db/db) animals of the indicated ages. TGF- $\beta$ mRNA was determined using quantitative PCR analysis. $n=6 \pm \mathrm{SD}$. (B) Cell fractionation of adipose tissue from lean and obese mice. Epididymal fat pads were isolated from 6-month-old male lean and ob/ob mice. Adipocytes $(\mathrm{AD})$ and stromal vascular cells $(\mathrm{S} / \mathrm{V})$ were separated by collagenase digestion followed by differential centrifugation. Total RNA was extracted from each fraction and TGF- $\beta$ mRNA levels were quantified by RT-PCR. $n=3$.

onstration that PAI- 1 is elevated in obesity (12), prompted us to more closely examine the role of TGF- $\beta$ in obesity. We initially determined whether TGF- $\beta$ expression was up-regulated in tissues from obese mice. Various tissues were removed from lean and obese mice and total RNA was prepared and analyzed for TGF- $\beta$ mRNA by quantitative RT-PCR. Figure 1A shows that TGF- $\beta$ mRNA levels were approximately 2 -fold higher in the adipose tissues of 3-month- old ob/ob mice compared with their lean counterparts, and 5-fold higher in 6-month-old ob/ob mice. This age-dependent increase in TGF- $\beta$ mRNA was not observed in the lean animals. TGF- $\beta$ mRNA expression was also increased (3- to 4-fold) in adipose tissue from the $\mathrm{db} / \mathrm{db}$ mouse (Fig. 1A), another murine model of obesity. Although TGF- $\beta$ mRNA was slightly elevated in muscle from 3-month-old obese mice, it was unchanged in the kidney, heart, brain, lung and liver (data not shown).

Experiments were performed to determine whether the increased TGF- $\beta$ mRNA in adipose tissue from obese mice is associated with increased production of TGF- $\beta$ protein. Local TGF- $\beta$ production was determined in explanted epididymal fat pads from 6-month-old ob/ob and lean mice. The obese and lean epididymal fat pads $(n=6)$ produced $1.15 \pm 0.4$ and $0.33 \pm$ $0.17 \mathrm{ng}$ TGF- $\beta / \mathrm{g}$ of tissue, respectively. When expressed as the mass of TGF- $\beta$ produced per unit of tissue DNA, the obese and lean adipose tissues produced $6.9 \pm 1.6$ and $2.27 \pm 1.7 \mathrm{ng}$ TGF- $\beta / \mathrm{mg}$ DNA, respectively. Although there was a 3- to 4-fold increase in the local production of TGF- $\beta$ protein from the obese adipose tissue, there were no significant differences in the circulating plasma levels of TGF- $\beta$ protein (i.e., $6.3 \pm 1.56 \mathrm{ng} / \mathrm{ml}$ total TGF- $\beta$ in ob/ob mice versus $4.9 \pm 1.8 \mathrm{ng} / \mathrm{ml}$ total TGF- $\beta$ in the lean). These data suggest that TGF- $\beta$ produced in the adipose tissue may function locally via autocrine and paracrine mechanisms.

Experiments were performed to identify the cells in adipose tissue expressing TGF- $\beta$ mRNA. Adipose tissues from lean and obese (ob/ob) mice were dissociated by collagenase treatment and subjected to differential centrifugation to separate lipid-laden mature adipocytes (floating cells) from the stromal/vascular (pellet) cells as described (28). The purity of the mature adipocyte fraction was documented by the failure to detect endothelial cells in this fraction by RTPCR (data not shown) using primers specific for von Willebrand factor as previously described (20). Figure 1B shows that TGF- $\beta$ mRNA levels were increased in both the mature adipocyte and the stromal/vascular cell fractions of the adipose tissues from the obese mice.

Adipose tissue contains a variety of cells besides adipocytes, including preadipocytes, vascular endothelial and smooth muscle cells, fibroblasts, local mast cells, and macrophages (31). Thus, in situ hybridization experiments were performed to further identify the TGF- $\beta$-express- 

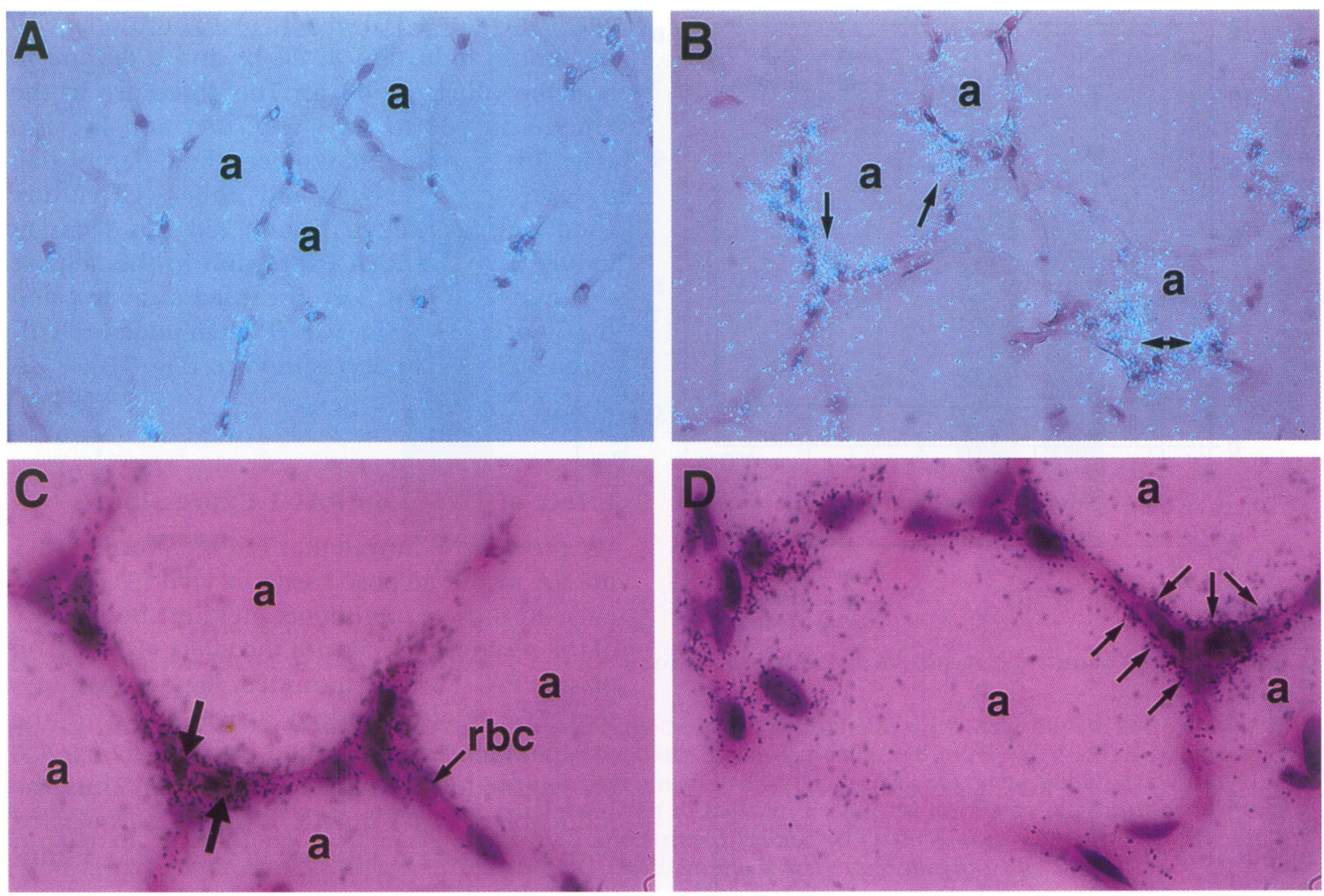

FIG. 2. Cellular localization of TGF- $\beta$ mRNA expression in adipose tissue from lean (+/?) and obese (ob/ob) mice.

Representative sections showing the cellular localization of TGF- $\beta$ mRNA. In situ hybridization was performed on sections of paraffin embedded adipose tissues from lean $(A, \times 400)$ and obese $(B, \times 400: C, D, \times 1000)$ mice. a, adipocyte; rbc, red blood cell. Arrows indicate positive hybridization signal in adipocytes (B and D) and capillary cells (C). Slides for in situ hybridization were exposed for 8 weeks at $4^{\circ} \mathrm{C}$ and stained with hematoxylin and eosin.

ing cells (Fig. 2). A weak, but consistent signal for TGF- $\beta$ mRNA was detected in cells in the fat from lean mice (Fig. 2A). However, a much stronger signal was associated with these cells in the fat from obese mice (Fig. 2B-D). The differences in the shapes of the nuclei of the positive cells and their different location, together suggests that TGF- $\beta$ mRNA is expressed by multiple cell types. For example, red blood cells (RBCs) are observed under the signal in Fig. $2 \mathrm{C}$, suggesting that capillary endothelial cells express TGF- $\beta$ mRNA. The observation that the hybridization signal is also localized outside of the capillaries (Fig. 2C, D) suggests that adipocytes also synthesize TGF- $\beta$, which is consistent with the results shown in Fig. 1B. No signal for TGF- $\beta$ was detected in the smooth muscle cells or endothelial cells of the larger vessels in the adipose tissue of the lean or obese mice (data not shown). In control experiments, no specific hybridization signal was detected using a sense TGF- $\beta$ riboprobe (data not shown).

\section{Effect of TNF- $\alpha$ and Insulin on TGF- $\beta$ Gene Expression in Adipose Tissues and in Cultured 3T3-L1 Adipocytes}

Since TNF- $\alpha$ and insulin are elevated in obesity $(3,13,14)$, we determined whether these agents could regulate the expression of TGF- $\beta$ in the adipose tissue. Lean CB6 mice were injected intraperitoneally with either $4 \mu \mathrm{g}$ of TNF- $\alpha$ or 10 units of insulin, or with vehicle alone. Tissues were removed 3, 6, and $24 \mathrm{hr}$ later, and total RNA was prepared and analyzed for TGF- $\beta$ mRNA by quantitative RT-PCR (Fig. 3A). TNF- $\alpha$ transiently increased TGF- $\beta$ mRNA expression in the adipose tissues with a maximum induction of 6- to 8-fold by $6 \mathrm{hr}$, and a return to basal levels by $24 \mathrm{hr}$ of treatment. Insulin did not appear to 

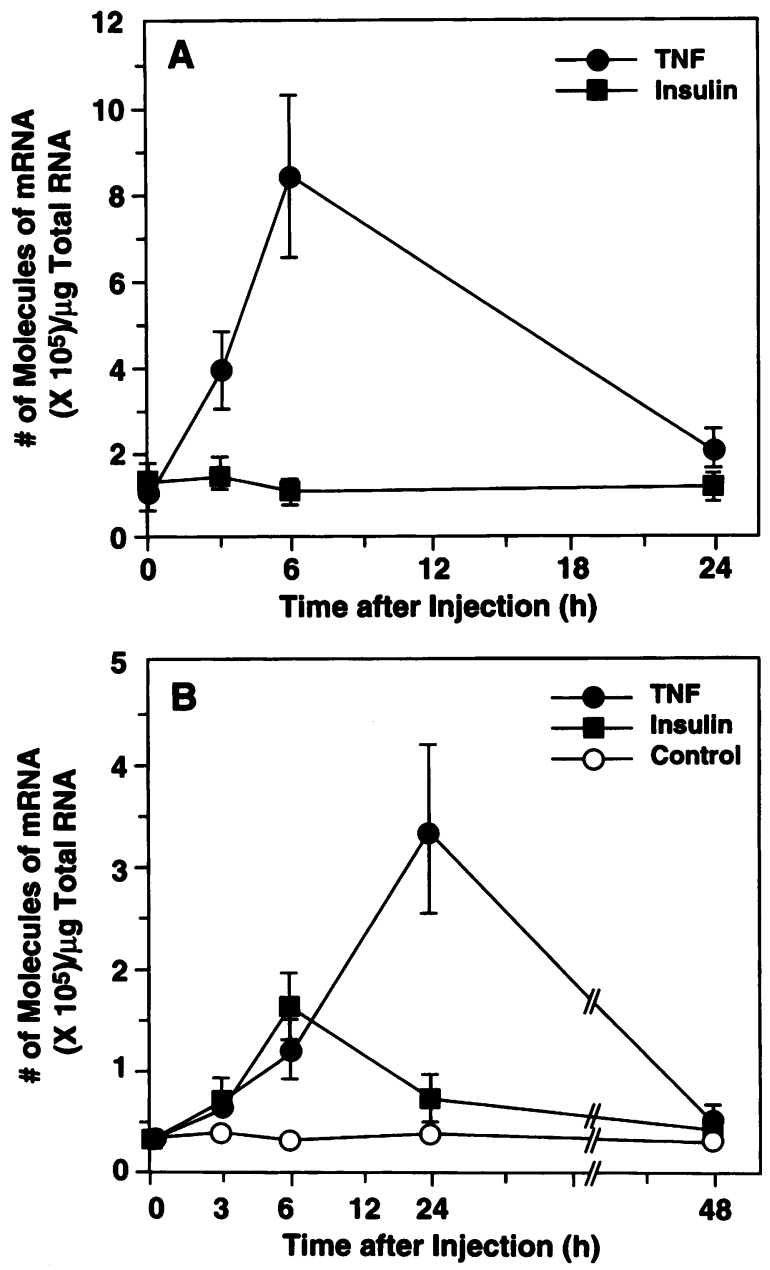

FIG. 3. Induction of TGF- $\beta$ mRNA expression by insulin and TNF- $\alpha$.

(A) Six-week-old lean mice were injected intraperitoneally either with 10 units of insulin, with $4 \mu \mathrm{g}$ of murine recombinant TNF- $\alpha$, or with saline. The epididymal fat pads were removed 3, 6, and $24 \mathrm{hr}$ later and total RNA was prepared and analyzed for TGF- $\beta$ gene expression by quantitative RT-PCR as described in Materials and Methods. Each time point on the graph represents the mean \pm SD of 3 animals. (B) 3T3-Ll adipocytes were grown and differentiated in 6-well tissue culture plates. The washed and differentiated cells were then treated with insulin (100 nM), TNF- $\alpha(5 \mathrm{ng} / \mathrm{ml})$, or media alone for the indicated times, and total RNA was isolated and the steady-state levels of TGF- $\beta$ mRNA were determined using quantitative RT-PCR. $n=6 \pm$ SD.

induce TGF- $\beta$ mRNA expression in the adipose tissue under these conditions.

In vitro experiments also were performed to examine the regulation of TGF- $\beta$ gene expression in adipocytes. Figure $3 \mathrm{~B}$ shows that treatment of 3T3-Ll adipocytes with TNF- $\alpha(5 \mathrm{ng} / \mathrm{ml})$ again increased TGF- $\beta$ mRNA expression, with maximum induction at $24 \mathrm{hr}$ and a decline to baseline values by $48 \mathrm{hr}$. The difference in the kinetics of the in vivo (Fig. 3A) and in vitro (Fig. 3B) response may reflect the different half lives of TNF- $\alpha$ in vivo and under cell culture conditions. Although insulin did not seem to induce TGF- $\beta$ mRNA expression in the adipose tissue in vivo (Fig. 3A), it caused a modest and transient increase in TGF- $\beta$ when added to cultured 3T3-Ll adipocytes in vitro (Fig. 3B).

\section{Effect of TGF- $\beta$ on PAI-1 Expression}

We previously showed that TGF- $\beta$ induced PAI- 1 mRNA in the adipose tissue in vivo (21). However, in those experiments, neither the identity of the responsible cells nor the effect of TGF- $\beta$ on plasma PAI- 1 was determined. Figure $4 \mathrm{~A}$ shows that TGF- $\beta$ also induced active PAI- 1 in the plasma, increasing it from a basal level of $1.2 \pm$ $0.05 \mathrm{ng} / \mathrm{ml}$ to $61.0 \pm 2.5 \mathrm{ng} / \mathrm{ml}$ by $3 \mathrm{hr}$. Thus, the induction of PAI- 1 mRNA by TGF- $\beta$ is associated with a concurrent increase in active PAI- 1 antigen in plasma.

Cell fractionation experiments were performed to begin to identify the cell-type(s) expressing elevated PAI- 1 levels after TGF- $\beta$ treatment. Adipose tissue was again subjected to differential centrifugation to separate mature adipocytes from the stromal/vascular cells, and the concentration of PAI-1 mRNA in the two cell fractions was determined by RT-PCR. Figure 4B shows that TGF- $\beta$ induced PAI- 1 mRNA both in the mature adipocyte fraction and in the stro$\mathrm{mal} /$ vascular cell fraction. In situ hybridization experiments demonstrate a weak, but consistent signal for PAI-1 mRNA in the smooth muscle cell layer within arteries in the adipose tissue from untreated mice (Fig. 5A). This signal was increased significantly in TGF- $\beta$-treated mice (Fig. 5B). Interestingly, in both instances, endothelial cells were negative for PAI-1 mRNA (Fig. 5A, B). Although no PAI-1 mRNA was detected by in situ hybridization in the fat from untreated mice (Fig. 5C), a strong positive signal was observed in the fat from TGF- $\beta$-treated mice (Fig. 5D). The PAI-1-positive cells morphologically (Fig. 5D) and biochemically (Fig. 4B) resembled adipocytes. Again, in control experiments, no specific hybridization signal was detected using a sense PAI-1 riboprobe (data not shown). 

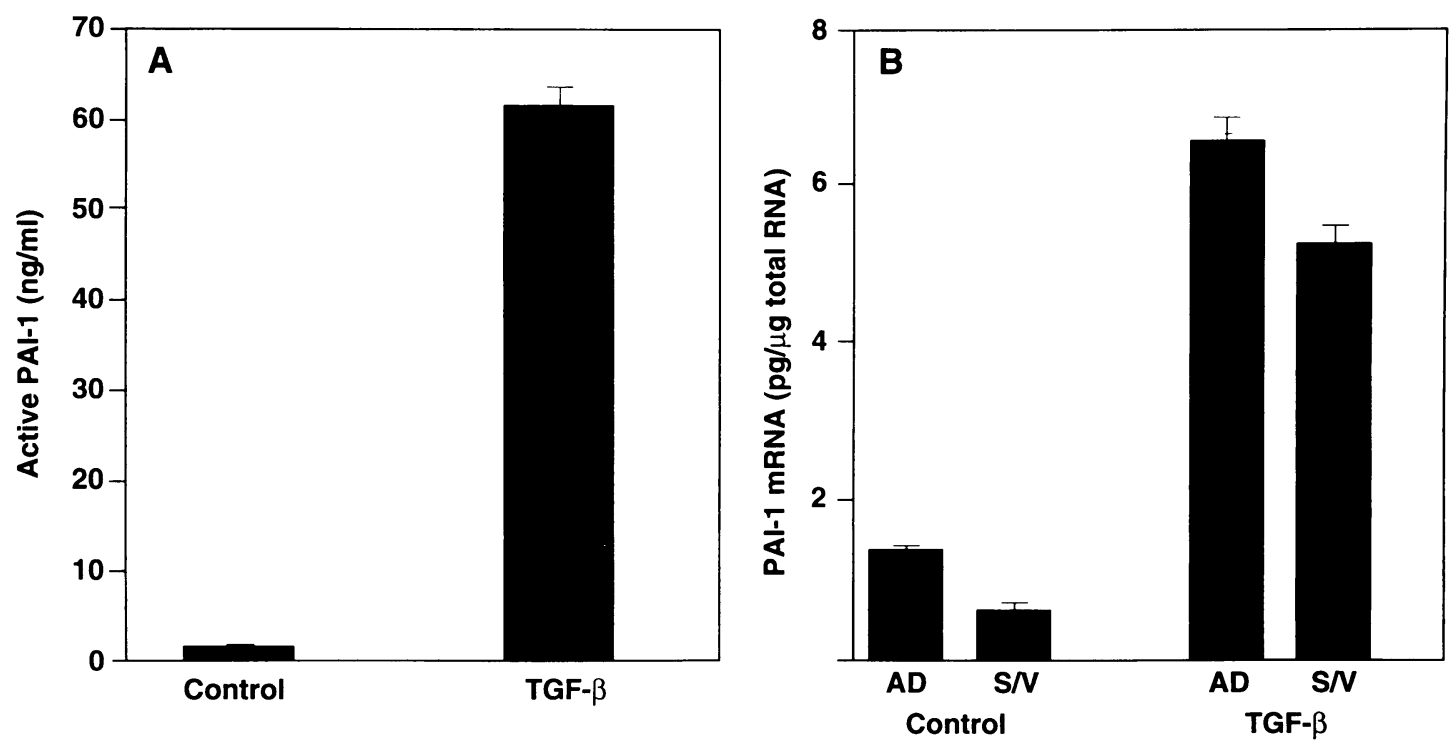

FIG. 4. Plasma PAI-1 activity and PAI-1 mRNA expression in cell-fractionated adipose tissue after TGF- $\beta$ treatment.

(A) Six- to eight-week-old male lean CB6 mice were injected intraperitoneally with $2 \mu \mathrm{g}$ human recombinant TGF- $\beta$ or diluent. The animals were sacrificed 3 hr later and blood was collected into 20 mM EDTA (final concentration). After centrifugation, the plasma was collected and active PAI- 1 (ng/ml) was determined using the t-PA binding assay. (B) Epididymal fat pads were isolated from 6- to 8-week-old CB6 mice $3 \mathrm{hr}$ after intraperitoneal injection of TGF- $\beta(2 \mu \mathrm{g})$. Mature adipocytes (AD) and stromal vascular cells (S/V) were separated by differential centrifugation and total RNA was prepared and PAI-1 mRNA levels were determined using RT-PCR. $n=3, \pm$ SD.

\section{Effect of TGF- $\beta$ on PAI-1 Expression in Cultured 3T3-L1 Adipocytes}

PAI- 1 synthesis by 3T3-Ll adipocytes is induced by TNF- $\alpha$ (20) and insulin (12), two mediators that are elevated in obesity. Thus, experiments were performed to determine whether PAI-1 expression by these cells also was induced by TGF- $\beta$. Figure $6 \mathrm{~A}$ shows that TGF- $\beta$ rapidly but transiently increased PAI-1 mRNA expression in these cells, with a maximum induction of $10-$ to 15 -fold within $3 \mathrm{hr}$, and a return to basal levels by $24 \mathrm{hr}$. PAI-l antigen in the conditioned medium was also induced by TGF- $\beta$ (Fig. 6A; inset) The 3T3-Ll cells responded to TGF- $\beta$ in a dosedependent manner (Fig. 6B), with an increase of 10- to 12 -fold at the maximum dose employed $(1 \mathrm{ng} / \mathrm{ml})$. The increase in PAI-1 mRNA paralleled the induction of PAI- 1 antigen (inset).

\section{DISCUSSION}

TGF- $\beta$ is a multifunctional cytokine that is produced by a variety of cells and is capable of regulating the growth and differentiation of many cell types (32). It has been implicated in a number of biological processes including cell adhesion and migration, extracellular matrix production, tissue remodeling, and wound repair $(32,33)$. In vivo, TGF- $\beta$ is present in platelets (33), peripheral blood monocytes, and tissue macrophages (34), and is released from these cells when they are activated. In vitro studies have shown that TGF- $\beta$ stimulates PAI- I biosynthesis by a variety of cells, including endothelial cells (35), smooth muscle cells (36), fibroblasts (37), epithelial cells (38), and several transformed cells lines, including hepatoma cells (39). Infusion of TGF- $\beta$ into rabbits increased plasma PAI- 1 activity (40), and infusion into mice induced PAI-1 mRNA in numerous tissues, the largest increase occurring in the adipose tissue (21). These in vitro and in vivo results suggest that TGF- $\beta$ is a potent regulator of PAI- 1 gene expression in adipose tissue. Moreover, they raise the possibility that if TGF- $\beta$ is elevated in obesity, it may stimulate PAI-1 gene expression and thus contribute to increased plasma PAI-I associated with this condition.

To evaluate whether TGF- $\beta$ was elevated in obesity, we determined the concentration of TGF- $\beta$ mRNA in the adipose tissue of lean and 

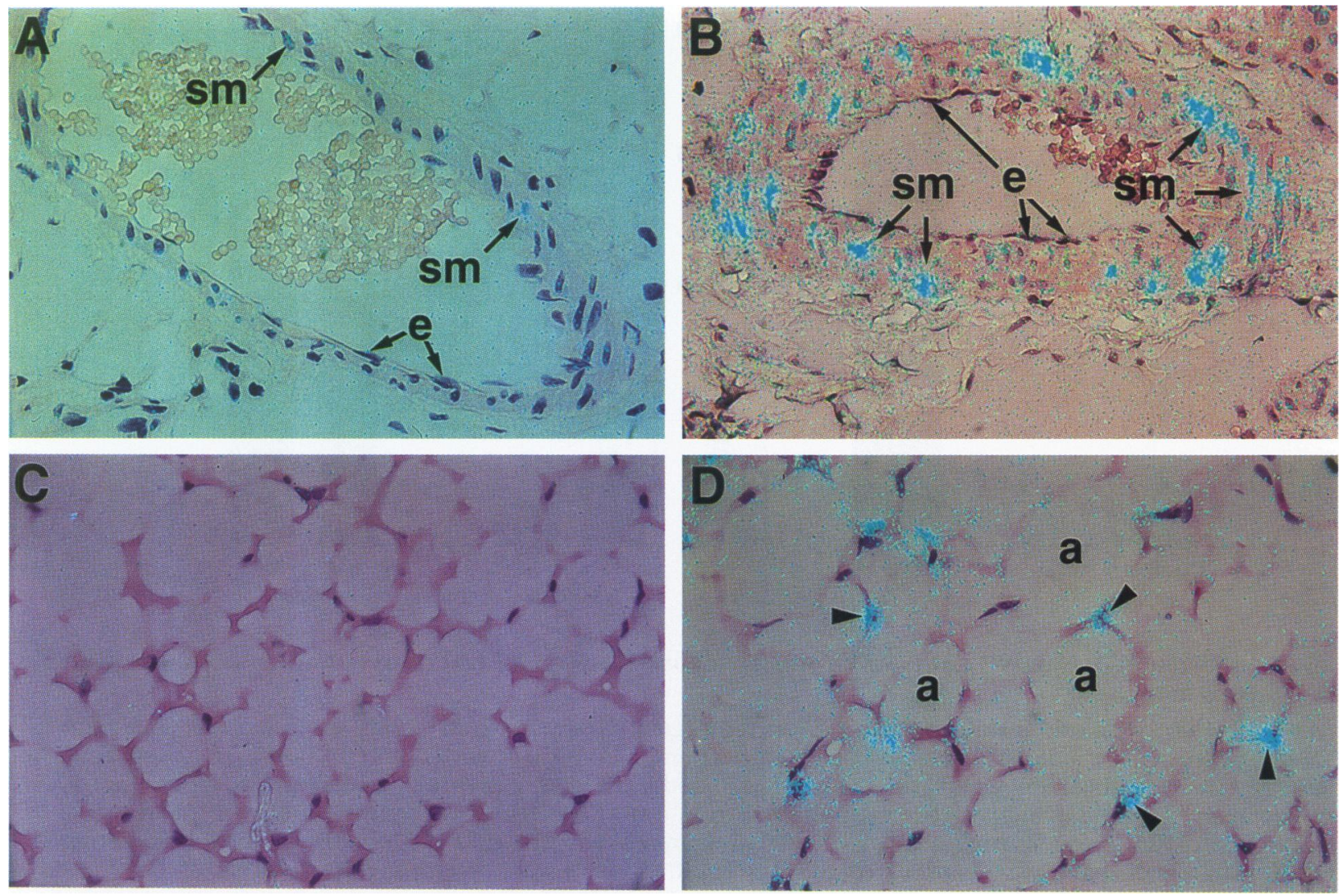

FIG. 5. Effect of TGF- $\beta$ on the cellular localization of PAI-1 mRNA in the adipose tissue of CB6 mice.

In situ hybridization was performed on paraffin sections of epididymal fat pad from untreated mice (A and $C$ ) and mice treated with TGF- $\beta(2 \mu \mathrm{g})$ for $3 \mathrm{hr}$ (B and D). Slides were exposed for 8 weeks at $4^{\circ} \mathrm{C}$ and stained with hematoxylin and eosin. e, endothelial cells; sm, smooth muscle cells; a, adipocytes. Arrowheads indicate positive signal for PAI-1 mRNA in the fat (D). Magnification was $\times 400$ for all sections.

obese mice. TGF- $\beta$ mRNA levels were significantly higher in the adipose tissue of both the ob/ob and $\mathrm{db} / \mathrm{db}$ mice when compared to their lean counterparts (Fig. 1A). Moreover, this increase was due to increased expression of TGF- $\beta$ mRNA by mature adipocytes and unidentified cells in the stromal/vascular fraction (Fig. 1B). In situ hybridization experiments demonstrated a TGF- $\beta$ hybridization signal in multiple cell types, including adipocytes (Fig. 2B-D). Microvascular endothelial cells may express TGF- $\beta$ mRNA since a positive signal was observed in cells within some capillaries (Fig. 2C). This possibility is under further investigation. Interestingly, TGF- $\beta$ mRNA was not detected in large vessels in adipose tissue from lean or obese mice (data not shown).

Experiments were performed to identify potential mechanisms that contribute to the chronically elevated levels of TGF- $\beta$ associated with the adipose tissues of obese mice. Both the ob/ob and $\mathrm{db} / \mathrm{db}$ mice are insulin resistant and hyperinsulinemic (41). Moreover, TNF- $\alpha$ is chronically elevated in the adipose tissue of insulin resistant obese rodents and humans $(13,14)$, and TNF- $\alpha$ can induce TGF- $\beta$ induction in rat endothelial cells and thyroid cells (42). We thus asked whether TGF- $\beta$ expression in the adipose tissue could be induced by either TNF- $\alpha$ or insulin. TNF- $\alpha$ induced TGF- $\beta$ mRNA in the adipose tissue of normal CB6 mice (Fig. 3A) and caused a strong induction of TGF- $\beta$ mRNA in cultured 3T3-L1 cells (Fig. 3B). These observations suggest that the chronically elevated TNF- $\alpha$ levels in the obese adipose tissue may act in an autocrine/ paracrine manner and contribute to elevated TGF- $\beta$ mRNA expression in obesity. Insulin failed to increase TGF- $\beta$ mRNA in adipose tissues of lean mice (Fig. 3A), even though it significantly increased the expression of PAI-1 mRNA 

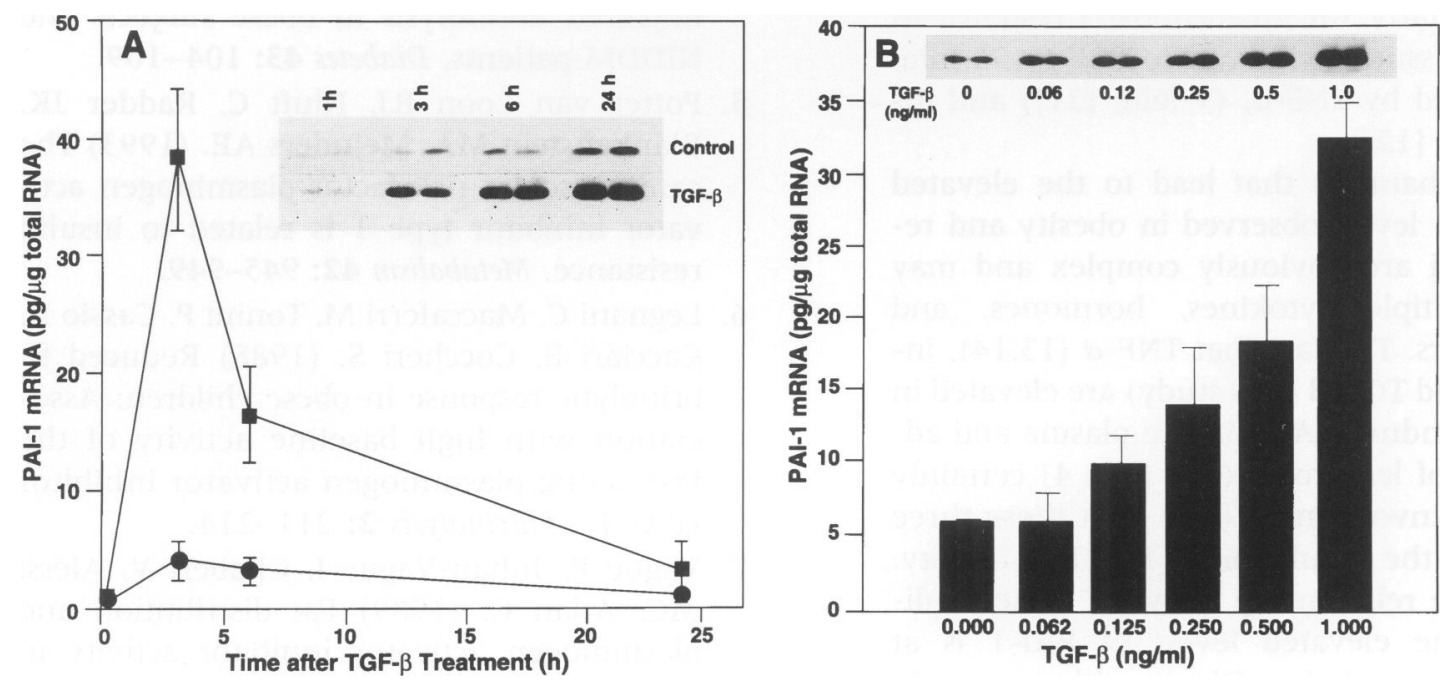

FIG. 6. Stimulation of PAI-1 expression in 3T3-L1 adipocytes by TGF- $\beta$.

3T3-L1 adipocytes were grown and differentiated in 6-well tissue culture plates as described previously (28). For kinetic studies (A), total RNA was isolated from untreated cells (O), and cells treated with $1 \mathrm{ng} / \mathrm{ml}$ TGF- $\beta$ ( $\square$ ) for the indicated times, and the steady-state levels of PAI-1 mRNA were determined using quantitative PCR. Inset: Conditioned medium $(20 \mu \mathrm{l})$ from untreated cells and cells treated with TGF- $\beta$ for various times were electrophoresed under nonreducing conditions on a 9\% SDS-PAGE gel and the proteins were transferred to nitrocellulose membranes. The membranes were analyzed for PAI-1 antigen by Western blotting using a polyclonal rabbit antimouse PAI-1 antiserum and the enhanced chemiluminescence detection system. For dose-response experiments (B), total RNA was isolated from untreated cells, and cells treated with increasing amounts of TGF- $\beta$ for $3 \mathrm{hr}$. Steady-state levels of PAI-1 mRNA were determined as above. Inset: Western blot analysis for PAI-1 antigen in conditioned medium $(20 \mu \mathrm{l})$ from untreated cells, and cells treated with increasing amounts of TGF- $\beta$ for 24 hr. For both $\mathrm{A}$ and $\mathrm{B}, n=6 \pm \mathrm{SD}$.

in adipose tissue (12). The addition of insulin to cultured 3T3-Ll cells caused a modest elevation of TGF- $\beta$ mRNA.

The increase in TGF- $\beta$ gene expression in adipose tissue in obesity may have broad implications in the pathophysiology of obesity and its related complications. TGF- $\beta$ inhibits in vitro proliferation of many cells, but it stimulates the growth of fibroblasts $(43,44)$. Moreover, TGF- $\beta$ has been shown to increase preadipocyte cell proliferation in many species (45-48). Thus, the augmented expression of TGF- $\beta$ in the obese adipose tissue may increase adipocyte precursor cell proliferation, thereby contributing to the excessive cellularity of the fat depots associated with the obese phenotype. Obesity and NIDDM are also associated with characteristic long-term complications, including microvascular kidney disease $(49,50)$ and atherosclerosis $(51,52)$. It is interesting to note in this regard that several investigators have reported overexpression of TGF- $\beta$ in the glomeruli in human and experimental diabetes $(50,53)$. Although TGF- $\beta$ expression was not elevated in the kidney of 3-month-old ob/ob mice, a 2- to 3-fold increase in TGF- $\beta$ mRNA was observed in the kidney of 6-month-old ob/ob mice, in comparison with its lean counterpart (data not shown).

Obesity and NIDDM are also associated with elevated PAI-1 (4-7), and administration of TGF- $\beta$ to lean mice caused a 60 -fold increase in active PAI-1 in plasma and increased PAI-1 mRNA in adipose tissue (Fig. 4). Cell fractionation studies (Fig. 4B) and in situ hybridization analysis (Fig. 5) of adipose tissues from TGF- $\beta$ treated mice demonstrated that TGF- $\beta$ induced PAI-1 mRNA expression in mature adipocytes and in the vascular smooth muscle cells of the arteries within the adipose tissue. TGF- $\beta$ did not induce PAI-1 mRNA expression in large vessel endothelial cells in the adipose tissue, which is in agreement with previous studies in the kidney (26). TGF- $\beta$ also stimulated PAI- 1 gene expression by cultured 3T3-Ll cells (Fig. 6), confirming the recent studies of Lundgren et al. (54). The TGF- $\beta$-mediated induction of PAI-1 in 3T3-Ll adipocytes was considerably higher than the response of these cells to TNF- $\alpha$ and insulin 
$(12,20)$. Similarly, the greatest PAI- 1 response in the adipose tissue in vivo was to TGF- $\beta$ (36-fold; [21]) followed by TNF- $\alpha$, (9-fold; [21]) and insulin (7-fold; [12]).

The mechanisms that lead to the elevated plasma PAI-1 levels observed in obesity and related NIDDM are obviously complex and may involve multiple cytokines, hormones, and growth factors. The fact that TNF- $\alpha(13,14)$, insulin (41), and TGF- $\beta$ (this study) are elevated in obesity and induce PAI- 1 in the plasma and adipose tissue of lean mice (20) (Fig. 4) certainly suggests the involvement of at least these three mediators in the regulation of PAI- 1 in obesity. However, the relationship between these mediators and the elevated levels of PAI-l is at present only correlative. Direct evidence would involve further experiments employing specific inhibitors or neutralizing antibodies. Obesity is associated with an excess of adipose tissue that frequently includes an elevated number of fat cells (55). This situation would tend to exacerbate the overproduction of TGF- $\beta$, PAI- 1 , and other molecules, whether the effects are achieved locally or systemically. These considerations emphasize the potential importance of excess adipose tissue mass for the synthesis of proteins and other molecules that may promote the development of pathophysiological complications associated with obesity.

\section{ACKNOWLEDGMENTS}

This work was supported by grant HL 47819 to DJL. The authors thank T. Thinnes for her technical assistance. In addition we thank M. McRae for her expert secretarial skills.

\section{REFERENCES}

1. Larsson B. (1991) Obesity, fat distribution and cardiovascular disease. Int. J. Obesity 15: 53-57.

2. Björntorp P. (1992) Abdominal fat distribution and disease: An overview of epidemiological data. Ann. Med. 24: 15-18.

3. DeFronzo RA, Ferrannini E. (1991) Insulin resistance: A multifaceted syndrome responsible for NIDDM, obesity, hypertension, dyslipidemia, and atherosclerotic cardiovascular disease. Diabetes Care 14: 173-194.

4. McGill JB, Schneider DJ, Arfken CL, Lucore CL, Sobel BE. (1994) Factors responsible for impaired fibrinolysis in obese subjects and NIDDM patients. Diabetes 43: 104-109.

5. Potter van Loon BJ, Kluft C, Radder JK, Blankenstein MA, Meinders AE. (1993) The cardiovascular risk factor plasminogen activator inhibitor type 1 is related to insulin resistance. Metabolism 42: 945-949.

6. Legnani C, Maccaferri M, Tonini P, Cassio A, Cacciari E, Coccheri S. (1988) Reduced fibrinolytic response in obese children: Association with high baseline activity of the fast acting plasminogen activator inhibitor (PAI-1). Fibrinolysis 2: 211-214.

7. Vague $P$, Juhan-Vague I, Chabert V, Alessi MC, Atlan C. (1989) Fat distribution and plasminogen activator inhibitor activity in nondiabetic obese women. Metabolism 38: 913-915.

8. Sprengers ED, Kluft C. (1987) Plasminogen activator inhibitors. Blood 69: 381-387.

9. Loskutoff DJ. (1988) Type 1 plasminogen activator inhibitor and its potential influence on thrombolytic therapy. Semin. Thromb. Hemost. 14: 100-109.

10. Schneiderman J, Loskutoff DJ. (1991) Plasminogen activator inhibitors. Trends Cardiovasc. Med. 1: 99-102.

11. Primrose JN, Davies JA, Prentice CRM, Hughes R, Johnston D. (1992) Reduction in factor VII, fibrinogen and plasminogen activator inhibitor- 1 activity after surgical treatment of morbid obesity. Thromb. Haemost. 68: 396-399.

12. Samad F, Loskutoff DJ. (1996) Tissue distribution and regulation of plasminogen activator inhibitor-1 in obese mice. Mol. Med. 2: 568-582.

13. Hotamisligil GS, Shargill NS, Spiegelman BM. (1993) Adipose expression of tumor necrosis factor- $\alpha$ : Direct role in obesity-linked insulin resistance. Science 259: 87-91.

14. Hotamisligil GS, Arner P, Caro JF, Atkinson RL, Spiegelman BM. (1995) Increased adipose tissue expression of tumor necrosis factor- $\alpha$ in human obesity and insulin resistance. J. Clin. Invest. 95: 2409-2415.

15. van Hinsbergh VW, Kooistra T, van den Berg EA, Princen HM, Fiers W, Emeis JJ. (1988) Tumor necrosis factor increases the production of plasminogen activator inhibitor in human endothelial cells in vitro and in rats in vivo. Blood 72: 1467-1473.

16. Kooistra T. (1990) The use of cultured human endothelial cells and hepatocytes as an 
in vitro model system to study modulation of endogenous fibrinolysis. Fibrinolysis 4: 33-39.

17. Vague $P$, Juhan-Vague I, Aillaud MF, Badier C, Viard R, Alessi MC, Collen D. (1986) Correlation between blood fibrinolytic activity, plasminogen activator inhibitor level, plasma insulin level, and relative body weight in normal and obese subjects. Metabolism 35: 250-253.

18. Mykkänen L, Rönnemaa $\mathrm{T}$, Marniemi J, Haffner SM, Bergman R, Laakso M. (1994) Insulin sensitivity is not an independent determinant of plasma plasminogen activator inhibitor-1 activity. Arterioscler. Thromb. 14: 1264-1271.

19. Asplund-Carlson A, Hamsten A, Wiman B, Carlson LA. (1993) Relationship between plasma plasminogen activator inhibitor- 1 activity and VLDL triglyceride concentration, insulin levels and insulin sensitivity: Studies in randomly selected normo- and hypertriglyceridaemic men. Diabetologia 36: 817825.

20. Samad F, Yamamoto K, Loskutoff DJ. (1996) Distribution and regulation of plasminogen activator inhibitor-1 in murine adipose tissue in vivo: Induction by tumor necrosis factor- $\alpha$ and lipopolysaccharide. J. Clin. Invest. 97: 37-46.

21. Sawdey MS, Loskutoff DJ. (1991) Regulation of murine type 1 plasminogen activator inhibitor gene expression in vivo: Tissue specificity and induction by lipopolysaccharide, tumor necrosis factor- $\alpha$, and transforming growth factor- $\beta$. J. Clin. Invest. 88: 13461353.

22. Schleef RR, Sinha M, Loskutoff DJ. (1985) Immunoradiometric assay to measure the binding of a specific inhibitor to tissue-type plasminogen activator. J. Lab. Clin. Med. 106: 408-415.

23. Wang AM, Doyle MV, Mark DF. (1989) Quantitation of mRNA by the polymerase chain reaction. Proc. Natl. Acad. Sci. U.S.A. 86: 9717-9721.

24. Yamamoto K, Loskutoff DJ. (1996) Fibrin deposition in tissues from endotoxin-treated mice correlates with decreases in the expression of urokinase-type but not tissue-type plasminogen activator. J. Clin. Invest. 97: 2440-2451.

25. Vanden Heuvel JP, Tyson FL, Bell DA. (1993) Construction of recombinant RNA templates for use as internal standards in quantitative RT-PCR. BioTechniques 14: 395398.

26. Keeton M, Eguchi Y, Sawdey M, Ahn C, Loskutoff DJ. (1993) Cellular localization of type 1 plasminogen activator inhibitor messenger RNA and protein in murine renal tissue. Am. J. Pathol. 142: 59-70.

27. Kehrl JH, Wakefield LM, Roberts AB, Jakowlew SB, Alvarez-Mon M, Derynck R, Sporn MB, Fauci AS. (1986) Production of transforming growth factor $\beta$ by human $T$ lymphocytes and its potential role in the regulation of $\mathrm{T}$ cell growth. J. Exp. Med. 163: 1037-1050.

28. Rodbell M. (1964) Metabolism of isolated fat cells: I. Effects of hormones on glucose metabolism and lipolysis. J. Biol. Chem. 239: 375-380.

29. Moore DD. (1996) Preparation of genomic DNA from mammalian tissue. In: Ausubel FM, Brent R, Kingston RE, et al. (eds) Current Protocols in Molecular Biology. John Wiley and Sons, New York, Vol. 1, pp. 221-222.

30. Green H, Kehinde O. (1975) An established preadipose cell line and its differentiation in culture: II. Factors affecting the adipose conversion. Cell 5: 19-27.

31. Markman B. (1989) Anatomy and physiology of adipose tissue. Clin. Plast. Surg. 16: 235-243.

32. McCartney-Francis NL, Wahl SM. (1994) Transforming growth factor beta: A matter of life and death. J. Leukocyte Biol. 55: 401409.

33. Sporn MB, Roberts AB, Wakefield LM, de Crombrugghe B. (1987) Some recent advances in the chemistry and biology of transforming growth factor- $\beta$. J. Cell Biol. 105: 1039-1045.

34. Assoian RK, Fleurdelys BE, Stevenson HC, Miller PJ, Madtes DK, Raines EW, Ross R, Sporn MB. (1987) Expression and secretion of type beta transforming growth factor by activated human macrophages. Proc. Natl. Acad. Sci. U.S.A. 84: 6020-6024.

35. Sawdey M, Podor TJ, Loskutoff DJ. (1989) Regulation of type 1 plasminogen activator inhibitor gene expression in cultured bovine aortic endothelial cells: Induction by transforming growth factor- $\beta$, lipopolysaccharide, and tumor necrosis factor- $\alpha$. J. Biol. Chem. 264: 10396-10401.

36. Reilly CF, McFall RC. (1991) Platelet-derived growth factor and transforming growth factor- $\beta$ regulate plasminogen acti- 
vator inhibitor-1 synthesis in vascular smooth muscle cells. J. Biol. Chem. 266: 9419-9427.

37. Lund LR, Riccio A, Andreasen PA, Nielsen LS, Kristensen P, Laiho M, Saksela O, Blasi F, Dano K. (1987) Transforming growth factor $-\beta$ is a strong and fast acting positive regulator of the level of type-1 plasminogen activator inhibitor mRNA in WI-38 human lung fibroblasts. $E M B O \mathrm{~J}$. 6: 1281-1286.

38. Thalacker FW, Nilsen-Hamilton M. (1987) Specific induction of secreted proteins by transforming growth factor- $\beta$ and 12-0-tetradecanoylphorbol-13-acetate. Relationship with an inhibitor of plasminogen activator. J. Biol. Chem. 262: 2283-2290.

39. Westerhausen DR, Hopkins WE, Billadello JJ. (1991) Multiple transforming growth factor- $\beta$-inducible elements regulate expression of the plasminogen activator inhibitor type-1 gene in Hep G2 cells. J. Biol. Chem. 266: 1092-1100.

40. Fujii S, Sobel BE. (1990) Induction of plasminogen activator inhibitor by products released from platelets. Circulation 82: 14851493.

41. Herberg L, Coleman DL. (1977) Laboratory animals exhibiting obesity and diabetes syndromes. Metabolism 26: 59-99.

42. Pekary AE, Berg L, Wang J, Lee $P$, Dubinett SM, Hershman JM. (1995) TNF-alpha, TSH, and aging regulate TGF-beta synthesis and secretion in FRTL-5 rat thyroid cells. Am. J. Physiol. 268: R808-R815.

43. Moses HL, Yang EY, Pietenpol JA. (1990) TGF- $\beta$ stimulation and inhibition of cell proliferation: New mechanistic insights. Cell 63: 245-247.

44. Moses HL, Coffey Jr RJ, Leof EB, Lyons RM, Keski-Oja J. (1987) Transforming growth factor beta regulation of cell proliferation. $J$. Cell Physiol. 5: 1-7.

45. Bortell R, van Wijnen AJ, Ramsey-Ewing AL, Stein GS, Stein JL. (1992) Differential regulation of $\mathrm{H} 4$ histone gene expression in 3T3-Ll pre-adipocytes during arrest of pro- liferation following contact inhibition or differentiation and its modulation by TGF beta 1. J. Cell. Biochem. 50: 62-72.

46. Jeoung DI, Tang B, Sonenberg M. (1995) Mitogenic response to TGF-beta in 3T3F442A cells. Biochem. Biophys. Res. Commun. 216: 964-969.

47. Butterwith SC, Goddard C. (1991) Regulation of DNA synthesis in chicken adipocyte precursor cells by insulin-like growth factors, platelet-derived growth factor and transforming growth factor-beta. J. Endocrinol. 131: 203-209.

48. Vassaux G, Negrel R, Ailhaud G, Gaillard D. (1994) Proliferation and differentiation of rat adipose precursor cells in chemically defined medium: Differential action of antiadipogenic agents. J. Cell. Physiol. 161: 249256.

49. Pfeiffer A, Schatz H. (1995) Diabetic microvascular complications and growth factors. Exp. Clin. Endocrinol. Diabetes 103: 7-14.

50. Border WA. (1994) Transforming growth factor-beta and the pathogenesis of glomerular diseases. Curr. Opin. Nephrol. Hypertension 3: 54-58.

51. Arrants J. (1994) Hyperinsulinemia and cardiovascular risk. Heart Lung 23: 118-122.

52. Sowers JR. (1992) Insulin resistance, hyperinsulinemia, dyslipidemia, hypertension, and accelerated atherosclerosis. J. Clin. Pharmacol. 32: 529-535.

53. Sharma K, Ziyadeh FN. (1995) Hyperglycemia and diabetic kidney disease. The case for transforming growth factor-beta as a key mediator. Diabetes 44: 1139-1146.

54. Lundgren $\mathrm{CH}$, Brown SL, Nordt TK, Sobel BE, Fujii S. (1996) Elaboration of type-1 plasminogen activator inhibitor from adipocytes: A potential pathogenetic link between obesity and cardiovascular disease. Circulation 93: 106-110.

55. Remacle C, and Gregoire F. (1992) Cellular and molecular biology in the study of the physiopathology of obesity. Acta Clinica Belgica 14: (Suppl.) 3-12.

Communicated by R. Bucala. Accepted on September 22, 1996. 